\title{
Demonstratives on the move: what translational shifts tell us about demonstrative determiners and definite articles in Spanish and Dutch.
}

\author{
Patrick Goethals \\ Faculty of Applied Language Studies, University College Ghent
}

\begin{abstract}
This paper explores the constructional meaning of NPs preceded by a demonstrative determiner and NPs preceded by a definite article, in both Spanish and Dutch. First, I will give a brief, general description of the meaning of the two constructions, focusing on three features: unique identifiability, deictic force and predicating force. Then, a contrastive analysis will show that demonstrative determiners and definite articles differ crosslinguistically. A quantitative analysis of translational shifts will reveal a systematic shift between Dutch demonstrative determiners and Spanish definite articles. Through the qualitative analysis of several subgroups of examples, I will show that the Dutch and Spanish paradigms differ with regard to the features of deictic and predicating force. Both Dutch demonstratives and definite articles seem to be more semantically bleached and hence more grammaticalized than their Spanish counterparts, which may well go some way to explaining the frequent and systematic translational shifts. Finally, I will draw attention to some specific phenomena, such as the cultural embeddedness of anaphoric relations, and the role of demonstratives in evoking a visual frame, which also motivate translational shifts between demonstratives and definite articles, but are better interpreted as local translator's decisions, rather than as systemic contrastive differences between Dutch and Spanish.
\end{abstract}

Keywords: demonstratives; definite articles; Spanish; Dutch; translational shifts; deictic force; predicating force

This paper is a contribution to the contrastive and translational analysis of noun phrases introduced by a demonstrative determiner (DemNP) or a definite article (DefNP) in Spanish (ES) and Dutch (NL). The questions that will be addressed are which paradigmatic shifts between DemNP and DefNP can be observed in translations, and what can these shifts teach us about cross-linguistic differences. In other words, do DemNPs and DefNPs have the same constructional meaning in the two languages, and do the two paradigms relate to each other in a similar way? And if there are differences, what are they, and how can they best be described?

Recent years have witnessed an increasing interest in the study of demonstratives in translated texts, focusing especially on translational shifts (see e.g. Da Milano 2007; Goethals 2007; Jonasson 2002; Labrador 2011; Vanderbauwhede 2011; Whittaker 2004; Wu 2004). This is an appealing line of research, from different perspectives. From a linguistic point of view, it is appealing because the translational shifts may point towards specific and subtle contrastive differences, even between closely related languages. These subtle contrastive differences are difficult to pinpoint solely on the basis of typological data, grammaticality judgments or monolingual corpus research (Cysouw and Wälchli 2007: 99; Dixon 2003; Johansson 2007; Wälchli 2007; Wu 2004: 23). From a translation theoretical point of view, it has been found that the shifts in the demonstrative paradigm are very frequent, and can be linked to the narratological characteristics of translations (Cuenca and Ribera 2011; Jonasson 2001; Mason and Şerban 2003) and the role of demonstratives in identifying the deictic center (Goethals and De Wilde 2009; Himmelmann 1996; Kleiber 2003; Philippe 1998). Although in Section 4, I will describe several groups of examples that illustrate the role of the translation process, the main focus will be the contrastive perspective (Section 5), looking at translational data as a heuristic tool to describe contrastive differences between Dutch and Spanish.

In order to compare the DemNP and DefNP paradigms in Dutch and Spanish, I will start Section 1 with a brief discussion of three concepts that have been described in previous theoretical research on the DemNP - DefNP distinction, namely (unique) identifiability, deictic force and predicating force. One of the main references for this study is Maes and Noordman 1995, a general analytical framework for describing DemNPs based on an 
empirical study of Dutch demonstratives. The distinction they draw between the identificational and the predicating role of DemNPs will be crucial in the interpretation of translational shifts in the corpus. Other references mainly come from functionalist and cognitive frameworks (Diessel 1999; Dixon 2003; Epstein 2002; Levinson 2004; Lyons 1999; Maes 1996; see Section 1). For Spanish, the paradigmatic contrast between DefNP and DemNP has been described in Eguren (1999) and NGRAE (2009: Section 17.4), whereas for Dutch, the main references are ANS 1997, Kirsner 1979, 1993 and the previously quoted Maes and Noordman 1995.

Since the focus is on the shifts between the DemNP and DefNP paradigms, I will pay little attention to the variation between the different demonstrative forms. For Spanish, various proposals have been made to describe the semantic differences between proximal leste/, medial distal /ese/ and marked distal /aquel/ (Delbecque 2011; Eguren 1999; García Fajardo 2006; Gómez Díez 2009; Jungbluth 2001, 2003; Macías Villalobos 2006; NGRAE 2009: Section 17). For Dutch, the intra-paradigmatic variation occurs between proximal /dit/ and distal /dat/ (Maes 1996; Kirsner 1979, 1993; Piwek, Beun \& Cremers 2007).

When discussing the examples, I will refer to some specific demonstrative uses, such as exophoric uses, endophoric anaphors, and discourse deictics. Since these terms have been used with different meanings, it might be useful at this point to define them briefly (for more extensive discussions, see Levinson 2004 or Lyons 1999). Where an exophoric NP (Please give me that book) refers to "concrete entities in the surrounding situation" (Diessel 2006: 470), an endophoric NP (Oh, you didn't read "1984" yet? You really should read that book) establishes a relation between the NP and a discourse entity that is evoked in the surrounding discourse (in the previous discourse in the case of anaphors, and in the following discourse in the case of cataphors, but since the corpus did not contain any translational shifts between DemNP and DefNP with cataphors, I will only use the term anaphors). Importantly, in exophors and anaphors not only does the destination point differ (situation versus discourse), the nature of the semiotic relation itself does too: in anaphoric relations there is a coreference relation between two linguistic expressions (the NP refers to a discourse entity that already was evoked previously by another linguistic expression; Lyons 1977: 668), whereas in an exophoric relation, there is a pointing relation (an NP pointing towards a physically present entity and thus converting it into a discourse entity). Like Levinson 2004, we could use the terms non-deictic versus deictic relation to refer to this distinction, but I also intend to use the term deictic in a broader sense, to indicate that an expression evokes the deictic center, or the origo of the deictic relation (Bühler 1934), as part of the scope of its meaning (scope is to be taken in the sense it has in Cognitive Grammar, as "the full array of conceptual content that [an expression] specifically evokes and relies upon for its characterization"; Langacker 2002: 4). Demonstratives are typical deictic expressions because they locate a referent vis-à-vis a deictic center, and thus also evoke, or establish, this deictic center. Since the deictic center can be evoked both in exophoric and anaphoric relations, terminologically speaking, deictic and anaphoric are categories that are not mutually exclusive. A third category is discourse deictics such as “'Daddy, I'm home' How do I miss those words”. As Levinson 2004 pointed out, "it is clearly not sufficient to distinguish simply between exophoric (deictic) and endophoric (non-deictic) [...] since discourse deixis is intra-text but deictic" (Levinson 2004: 107-108). In other words, discourse deictics do not establish a coreference relation, but point to a physically present entity, i.e. the linguistic sign, which is physically present because the reference involves not only the signified but also the signifier as such. I will use the term discourse deictics in a restrictive way, only including references to entities such as linguistic signs, or speech acts (e.g. A: Are you single? B: I hate that question.), that can be considered as present in the speech situation. Other authors (Cornish 2007; Diessel 1999, 2006; Eguren 
1999), following the rather confusing category of impure textual deixis proposed by Lyons 1977, also use the term to refer to examples such as John said that he would like to visit the cathedral, but Peter didn't like that idea where the NP establishes a link with a larger discourse segment, such as a clause, a proposition, or several propositions. In my view, it is more appropriate to consider these relations as anaphoric, since there is coreference, although with a larger discourse segment, and not with an NP. Other frameworks therefore distinguish between direct anaphors, with a nominal antecedent, and other anaphors, with more complex antecedents. Various terms have been proposed for the latter category, such as indirect anaphora (Botley 2006) or complex anaphora (Consten, Knees and Schwarz-Friesel 2007), but since this question is not at the center of this paper's argumentation, I will avoid further terminological difficulties by referring explicitly to anaphors with nominal antecedents and anaphors with propositional antecedents as and when required.

\section{The constructional meaning of DemNP and DefNP}

In this section I will sketch the constructional meaning of DefNP and DemNP by referring to three features: (a) (unique) identifiability, which is a shared feature of DefNP and DemNP, (b) deictic force and (c) predicating force. The last two features differ with respect to the two paradigms. Although in this section, we will see that the same general description applies to Dutch and Spanish, in the subsequent sections I will argue that deictic force and predicating force are not binary values, but rather a matter of degree, and that the two languages may differ with regard to the relative values that are associated with the paradigms DefNP and DemNP.

\section{1. (Unique) identifiability and the deictic domain}

DemNP and DefNP are definite constructions and thus signal to the hearer that the discourse entity to which they refer is uniquely identifiable (see e.g. Lyons 1999: Ch. 7). The most obvious cases of identifiability are those in which the NP refers to a pre-existing discourse entity, for example when the NP refers exophorically to a visible referent in the context (1), anaphorically to an element in the previous discourse (2), or in recognitional uses (Levinson 2004: 108) when the hearer and speaker have shared knowledge of the concept or entity (3). As we can see in (1-3), both DefNP and DemNP occur in these contexts.

ES Dame $\{$ el $\sim$ ese $\}$ cenicero. (invented example) $)^{1}$

NL Geef mij $\{$ de $\sim$ die $\}$ asbak eens.

'Give me $\{$ the $\sim$ that $\}$ ashtray.'

(2) ES Se preguntó si el suicidio tendría algo que ver con aquello. $\{$ El $\sim$ Este $\sim$ Ese\} pensamiento lo estremeció. (invented example)

NL Hij vroeg zich af of de zelfmoord daar iets mee te maken had. \{De $\sim$ Deze Die\} gedachte deed hem huiveren.

'He wondered if the suicide had anything to do with it. \{The $\sim$ This $\sim$ That thought shook him.'

(3) ES ¿Recuerdas \{el ese\} museo que visitamos cuando estábamos en Madrid? (invented example)

NL Herinner je je $\{$ het $\sim$ dat\} museum dat we bezocht hebben toen we in Madrid waren?

'Do you remember $\{$ the $\sim$ that $\}$ museum we visited when we were in Madrid?' 
However, there are also definite nominal phrases that "do not refer to pre-existing entities but, rather, create entities which are to be entered into the discourse for the first time" (Epstein 2002: 44). This means that there may be no exophoric, anaphoric or recognitional link, and the concept may be entirely new to the hearer. In these cases, the discourse entity is identifiable for the hearer on the basis of the description that is offered in the NP. Interestingly, only DefNP can yield this interpretation. So, in (4), with DefNP the referent may be entirely new to the hearer, whereas in the case of a DemNP, it must have been mentioned previously, or else the hearer must be familiar with the concept:

ES En lo que sigue, describiremos $\{e l \neq$ ese $\}$ problema clasificatorio que plantean las formas demostrativas. (invented example)

$N L \quad$ In wat volgt zullen we $\{$ het $\neq$ dat\} classificatieprobleem van de demonstratieve vormen beschrijven.

'In what follows, we will describe $\{$ the $\neq$ that $\}$ classification problem of the demonstrative forms.'

This means that the construction DefNP conveys that the discourse entity can be identified on the basis of the information given in the NP. It is up to the hearer to infer whether the identifiable concept is coreferential with a prior discourse entity, whether it refers exophorically to the context, or whether it is indeed new. A DemNP, however, not only marks the identifiability of the discourse entity, it always relates this to the deictic center. The discourse referent is identifiable as a consequence of its already being present in the deictic domain (a textual domain in the case of endophors, or a situational domain in the case of exophors). This excludes its use in examples such as (4), where the discourse referent is totally new. I will call this the deictic force of DemNP.

Deictic force explains why DemNPs do not occur in the so-called associative or bridging anaphors (García Fajardo 2006; Lyons 1999: 4; NGRAE 2009: Section 17.4f). In (5), la cocina is a new referent, identifiable as the kitchen of my house through association with the apartment-frame mentioned in the preceding context. DemNP is not possible ${ }^{2}$ because its use would imply that the referent is already present in the deictic domain, instead of being indirectly identifiable through an associative or inferential link with another concept:

$$
\begin{aligned}
& \text { ES Ayer mis padres vieron por primera vez mi nuevo piso. Les gustó mucho \{la } ~ \\
& \text { ?esta } \sim \text { ?esa } \sim \text { ?aquella\} cocina. (invented example) } \\
& \text { GListeren zagen mijn ouders voor de eerste keer mijn nieuwe flat. Ze vonden \{de } \\
& \sim \text { ?deze } \sim \text { ?die\} keuken heel mooi. } \\
& \text { 'Yesterday my parents saw my new apartment for the first time. They liked } \\
& \text { very much }\{\text { the } \sim \text { ?this } \sim \text { ?that }\} \text { kitchen.' }
\end{aligned}
$$

The relation with the deictic domain is also the reason why a DemNP cannot render a generic meaning in the way a DefNP can in Spanish and Dutch. The reason is that the link with the deictic domain implies some kind of contrastive reading (García Fajardo 2006: 178). As is evident in $(6)^{3}$, DemNP esta/esa literatura or deze/die literatuur refers necessarily to a type of literature (presumably defined in the previous context), as opposed to other members of the conceptual category literature, whereas DefNP la literatura / de literatuur ('literature' in English) can evoke the general concept of literature as such. The identifiability that is marked by DefNP in Spanish and Dutch is here to be interpreted as identifiable-as-a-genericconcept. 

example)

NL De tijden zijn niet gunstig voor $\{$ de $\neq$ dezeldie $\}$ literatuur.

'Times are not conducive to $\{$ the $(\varnothing) \neq$ this/that $\}$ literature.'

Finally, contrastive reading is on the basis of one of the most salient uses of demonstratives, namely when they are used to distinguish between two or more instances of the same category:

$$
\begin{aligned}
& \text { ES Guardaré }\{* e l \sim \text { estelese\} libro y devolveré los otros. (invented example) } \\
& N L \quad I k \text { zal }\{* \text { het } \sim \text { dit/dat }\} \text { boek houden en de rest teruggeven. } \\
& \text { 'I will keep }\{* \text { the } \sim \text { this/that }\} \text { book and return the others.' }
\end{aligned}
$$

Figure 1 depicts the first two dimensions of the constructional meaning of DemNP and DefNP. The construction DemNP instantiates a deictic center as the anchor of the deictic domain in which the discourse entity is identified: the deictic center is part of the scope of the constructional meaning of DemNP (illustrated with bold lines), whereas the construction DefNP gives a description of the discourse referent, marks its identifiability (illustrated with a square box), but does not necessarily evoke a deictic center as part of its scope.

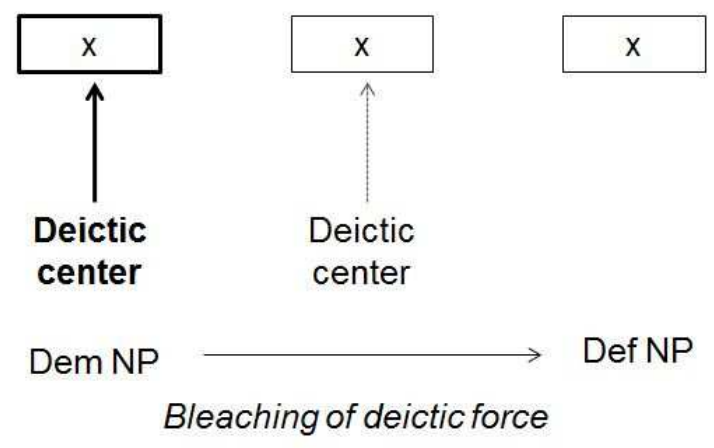

Figure 1. The deictic force of DemNP and DefNP

It is important to note that DemNP and DefNP are two poles that are connected diachronically and synchronically. It is a well-known fact that in a wide variety of languages, definite articles evolve diachronically from demonstrative determiners (Diessel 1999: 128129). This diachronic evolution consists of a semantic bleaching process or "semantic weakening" (Lyons 1999: 107) that affects particularly the instantiation of the deictic domain. Indeed, evolving from the demonstrative pole towards the definite article pole, the deictic domain gradually falls outside the scope of the constructional meaning, and hence the construction "loses deictic force" (Diessel 2006: 476). Synchronically, DemNP and DefNP show a considerable distributional overlap. As examples such as (1-3) illustrate, while they have the same referential denotation, the two constructions only differ in the degree to which the deictic domain is evoked as part of the scope of the meaning. This means that there are many contexts where both forms can be used, conveying subtly different meaning effects (for Spanish, see NGRAE 2009: Section 17.4a; for Dutch, see ANS 1997: Section 5.6.3.1).

\subsection{Identificational and predicating communicative functions}

Thus far, I have focused on the marking of the deictic domain and the identification of the referent. However, as Maes and Noordman (1995) claim, [DemNPs] "cannot be described sufficiently in terms of their identificational capacity" (1995: 259), but it is also necessary to 
focus on what DemNPs communicatively do with the referent. Following on from what Maes and Noordman (1995) say, I will argue that DemNPs can be distinguished from DefNPs in the sense that the construction assigns to the NP a predicating communicative function.

In DefNP, the NP has primarily an identifying function: the information given by the NP must restrict the reference in such a way that the hearer will be able to identify the discourse entity in a unique way (be it as a specific instance, a type, or as a generic concept). In DemNP, however, Dem indicates that the discourse entity is identifiable through its relation with the deictic center, and therefore the NP is not primarily assigned an identifying function, but acquires an additional communicative function: the information in the NP is not primarily given to identify the referent, but rather to comment on it. Maes and Noordman (1995) call this the "modifying" or "predicating" function of DemNPs. ${ }^{4}$

This difference explains why in (8) DemNP esa película maravillosa is more acceptable than DefNP la película maravillosa. In the DefNP construction, the postnominal adjective maravillosa is interpreted as a restrictive determiner that should help uniquely identify the film, but this restrictive and identifying function conflicts with its inherent evaluative meaning. The fact that this conflict does not arise with DemNP shows that the NP is not expected to be identifying (in the deictic domain it should be clear which film we are talking about), but is open to introducing predicating elements, such as evaluative adjectives. In Dutch and English too, DefNP sounds less natural than DemNP.

$$
\begin{aligned}
& \text { ES Ayer vi \{?la } \sim \text { esa\} película maravillosa. (NGRAE 2009: Section 17.4c-d) } \\
& \text { NL Gisteren heb ik }\{\text { ?de } \sim \text { die\} prachtige film gezien. } \\
& \text { 'Yesterday I saw }\{\text { ?the } \sim \text { that }\} \text { wonderful film.' }
\end{aligned}
$$

Example (9) is a special case to further illustrate the difference between an identificational and a predicating function (for a similar example, see Maes and Noordman 1995: 270). We notice that DefNP el "Águila de Toledo" ("the "Eagle of Toledo"') cannot be substituted by a DemNP, the reason being that the description that is given in the NP is presented as a nickname, a conventional and well-known description used to identify the referent. The use of DemNP would, in contrast, suggest that this is a judgment about Bahamontes made by the speaker himself, but this clearly conflicts with the use of the capitals and the quotation marks.

$$
\begin{aligned}
& \text { ES Bahamontes, }\{e l \sim * e s e\} \text { "Águila de Toledo", ..., (es.wikipedia.org) } \\
& N L \quad \text { Bahamontes, }\{\text { de } \sim \text { *die\} "Adelaar van Toledo", ... (nl.wikipedia.org) } \\
& \text { 'Bahamontes, }\{\text { the } \sim \text { *that }\} \text { "Eagle of Toledo", ... }
\end{aligned}
$$

\section{A contrastive view on DemNP and DefNP}

In the previous section, I outlined the constructional meaning of DemNP and DefNP. This generic description applies to Dutch and Spanish alike, as indeed, the examples in both languages behave in a very similar way. Does this mean that there are no contrastive differences? It would be far too premature to conclude anything of the sort, and, in fact, the results of the translational analysis will prove otherwise (see Section 3). As I said in Section 1 , the distinguishing features deictic force and predicating force are not absolute characteristics, but rather features that may be more or less prominent depending on the context (from a synchronic point of view), or features that may have bleached to different degrees (from a diachronic point of view). Hence, assuming that the general description is valid in both languages, the contrastive question that needs to be addressed concerns the relative force of the distinguishing features. In other words, have contemporary Dutch and 
Spanish DefNP constructions lost their original demonstrative meaning to the same degree? And to what extent have contemporary Dutch and Spanish DemNP constructions already undergone an incipient grammaticalization process that bleaches their inherent deictic and predicating force?

The key challenge we are faced with is, therefore, to verify whether the transition points between the exclusive and overlapping domains of DemNP and DefNP are identical crosslinguistically. Before proceeding to the empirical analysis, I want to make a brief methodological digression and explain why it is useful to introduce a relatively new type of data, i.e. translational data, into this field.

Methodologically, the cross-linguistic comparison of subtle semantic and pragmatic contrasts is very complex. The traditional method of grammaticality judgments raises some problems. As we have seen in Section 1, the method that defines the contexts in which only one construction is grammatical does not give very fine-grained results from a contrastive point of view, since closely related languages such as Spanish and Dutch behave in a similar or even identical way in these results. If we want to further refine the description, grammaticality judgments will also be increasingly difficult to make, since in many contexts DemNPs and DefNPs are both grammatical, although they can yield slightly different connotations.

Interesting results are also obtained by research on comparable monolingual corpora. As is shown by Vanderbauwhede (2011) on French and Dutch, this method can provide insight into the relative frequency of DemNPs, and into the relative frequency of different uses. Yet, with this method, it remains difficult to compare cross-linguistically the behavior of DefNPs and DemNPs in specific contexts. In order to operationalize the coding process of the corpus, the categories are necessarily rather broadly defined (e.g. direct and indirect anaphoric, cataphoric, exophoric, discourse-deictic or recognitional uses), and it remains very difficult to judge whether the other language would use the same construction in a particular context or not.

Therefore, it is useful to search complementary data in corpora of translated texts and to focus on translational shifts (Da Milano 2007 for a typological study; Jonasson 2001, 2002 for Swedish-French; Whittaker 2004 for Norwegian-French and Vanderbauwhede 2011 for Dutch-French). When systematic trends in translational shifts are found, and these shifts occur in both translation directions, we can presume that there is an underlying contrastive difference between the two languages (Goethals 2007). Translational data provides us with a kind of independent judgment: it is an independent translator who has decided not to use the most congruent form. Moreover, the method of looking specifically at translational shifts also shows up an economic and heuristic advantage, in the sense that it guides us towards the richest data, where contrastive differences are most likely to be found.

Of course, not all translational shifts can be attributed to contrastive, linguistic differences. When we consider translations, we soon realize that translators do not necessarily choose the most congruent construction. A close examination of the examples of the corpus, where we combine a quantitative and qualitative approach, should help us distinguish between systematic and unsystematic shifts, and between shifts that are presumably the result of the translator's decisions, and others that may reveal systematic differences between Spanish and Dutch.

\section{Translational shifts analysis: a quantitative approach}

In this section, I will present the quantitative data that is extracted from a bidirectional corpus of literary and essayistic texts, originally written in Spanish or Dutch, and their respective translations. ${ }^{5}$ In particular, I will focus on the question how frequently DemNPs 
are translated by DefNPs, or, vice versa, DemNPs are used to translate DefNPs. This data should grant us a first insight into the plausibility that there are indeed cross-linguistic differences with respect to the relative balance between the two constructions.

Since we consider shifts between two constructions in two languages in two corpora, these data are rather complex. The left-hand column of Table 1 lists the different Dutch (NL) and Spanish (ES) alternatives of DemNP: proximal /dit/ and distal /dat/ for Dutch, and proximal /este/, medial distal /ese/ and marked distal /aquel/ for Spanish. The results are given for the two translation directions (NL $\rightarrow \mathrm{ES}$ and $\mathrm{ES} \rightarrow \mathrm{NL}$ ). For each translation direction, the total number of DemNPs is given, along with the number of DemNPs that are translated by, or are used to translate a DefNP in the other language. This is, for example, how the first line (Dutch proximal /dit/) should be read: in the translation direction NL $\rightarrow \mathrm{ES}$, where Dutch is the source language and Spanish the target language, there is a total number of 98 occurrences of Dutch proximal DemNP; 10 are translated by a Spanish DefNP, which represents $10.2 \%$ of the Dutch proximal DemNPs in this corpus. In the corpus ES $\rightarrow$ NL, where Spanish is the source language and Dutch the target language, there is a total number of 187 occurrences of Dutch proximal DemNP; 26, or 13.9\%, are used to translate a Spanish DefNP. Adding up the results for the two translation directions (NL↔ES), we notice that there is a total number of 285 Dutch proximal DemNPs, 36 of which, or $12.6 \%$, are translated by, or are a translation of a Spanish DefNP.

Table 1. Translation shifts DemNP $\leftrightarrow$ DefNP in the bidirectional corpus.

\begin{tabular}{|c|c|c|c|c|c|c|c|c|c|}
\hline & \multicolumn{3}{|c|}{ Corpus NL $\rightarrow$ ES } & \multicolumn{3}{|c|}{ Corpus ES $\rightarrow$ NL } & \multicolumn{3}{|c|}{ Total NL $\leftrightarrow \mathrm{ES}$} \\
\hline NL & $\begin{array}{l}\mathrm{n}^{\circ} \text { of } \mathrm{NL} \\
\text { DemNP }\end{array}$ & \multicolumn{2}{|c|}{$\begin{array}{l}\text { NL Dem translated } \\
\text { by ES Def }\end{array}$} & $\begin{array}{l}\mathrm{n}^{\circ} \text { of NL } \\
\text { DemNP }\end{array}$ & \multicolumn{2}{|c|}{$\begin{array}{l}\text { NL Dem used to } \\
\text { translate ES Def }\end{array}$} & $\begin{array}{l}\mathrm{n}^{\circ} \text { of } \mathrm{NL} \\
\text { DemNP }\end{array}$ & \multicolumn{2}{|c|}{$\begin{array}{c}\text { NL DemNP } \leftrightarrow \text { ES } \\
\text { DefNP }\end{array}$} \\
\hline $\begin{array}{c}\text { proximal } \\
\text { /dit/ }\end{array}$ & 98 & 10 & $10.2 \%$ & 187 & 26 & $13.9 \%$ & 285 & 36 & $12.6 \%$ \\
\hline $\begin{array}{l}\text { distal } \\
\text { /dat/ }\end{array}$ & 404 & 67 & $16.5 \%$ & 405 & 77 & $19.0 \%$ & 809 & 144 & $17.8 \%$ \\
\hline total & 502 & 77 & $15.3 \%$ & 592 & 103 & $17.4 \%$ & 1094 & 180 & $16.4 \%$ \\
\hline ES & $\begin{array}{l}\mathrm{n}^{\circ} \text { of ES } \\
\text { DemNP }\end{array}$ & $\begin{array}{l}\text { ES D } \\
\text { transla }\end{array}$ & $\begin{array}{ll}\text { used to } \\
\text { Def }\end{array}$ & $\begin{array}{l}n^{\circ} \text { of ES } \\
\text { DemNP }\end{array}$ & $\begin{array}{r}\text { ES D } \\
\text { b }\end{array}$ & $\begin{array}{l}\text { anslated } \\
\text { Def }\end{array}$ & $\begin{array}{l}\mathrm{n}^{\circ} \text { of ES } \\
\text { DemNP }\end{array}$ & ES D & $\begin{array}{l}\mathrm{P} \leftrightarrow \mathrm{NL} \\
\mathrm{NP}\end{array}$ \\
\hline $\begin{array}{c}\text { proximal } \\
\text { lestel }\end{array}$ & 179 & 3 & $1.7 \%$ & 155 & 8 & $5.2 \%$ & 334 & 11 & $3.3 \%$ \\
\hline $\begin{array}{c}\text { medial- } \\
\text { distal } \\
\text { lesel }\end{array}$ & 207 & 5 & $2.4 \%$ & 200 & 9 & $4.5 \%$ & 407 & 14 & $3.4 \%$ \\
\hline $\begin{array}{c}\text { marked } \\
\text { distal } \\
\text { /aquel/ }\end{array}$ & 80 & 7 & $8.8 \%$ & 82 & 5 & $6.1 \%$ & 162 & 12 & $7.4 \%$ \\
\hline total & 466 & 15 & $3.2 \%$ & 466 & 22 & $5.0 \%$ & 903 & 37 & $4.1 \%$ \\
\hline
\end{tabular}

The data reveals clear systematic tendencies. The most important finding ${ }^{6}$ is that the pattern NL DemNP $\leftrightarrow$ ES DefNP is far more frequent (16.4\%) than the pattern ES DemNP $\leftrightarrow$ NL DefNP (4.1\%) (p-value 0). Importantly, the results are not related to the translation direction: in the corpus NL $\rightarrow \mathrm{ES}, 15.3 \%$ of the Dutch DemNPs are translated by a Spanish DefNP, and, similarly, in the corpus ES $\rightarrow$ NL, $17.4 \%$ of the Dutch DemNPs are translations of a Spanish DefNP in the source text (the difference between the subcorpora is not statistically significant: $\mathrm{p}$ 0.36). For the Spanish DemNPs, the results are also similar in both translation directions, with a non-significant difference between the subcorpora (3.2\% and 5.0\%; p 0.24). Hence, the data suggests that there is a contrastive linguistic difference, and that in some 
contexts, Dutch chooses a DemNP where Spanish prefers a DefNP construction. Given the fact that the translation direction does not play a statistically significant role, I will refrain from comparing the examples from the two subcorpora, but instead focus on the overall DemNP $\leftrightarrow$ DefNP contrast, irrespective of whether the demonstrative form occurs in the source text or in the target text.

The data shows the usefulness of a bidirectional corpus. If we considered one of the two translation directions only, it would be impossible to distinguish between the effect of a contrastive difference, and the effect of some hypothetic systematic translational tendency, for example a tendency to use less deictic forms in translations (i.e. DefNP replacing DemNP), or, on the contrary, a tendency to reinforce the deictic dimension in translations (i.e. DemNP replacing DefNP). The data clearly shows that there is no evidence to support such a hypothesis.

A closer analysis of the examples should make these general observations much more specific, and show the concrete dimensions of the contrastive difference. While the argumentation is mainly based on a qualitative discussion of the examples, it is combined with a quantitative argument. Specifically, I will consider how frequent certain phenomena are in the two groups of DefNP $\leftrightarrow$ DemNP translational shifts, i.e. examples with the pattern Dutch DemNP $\leftrightarrow$ Spanish DefNP (the most frequent situation) and examples with the pattern Spanish DemNP $\leftrightarrow$ Dutch DefNP (which could be considered as possible "counterexamples"). The overall proportion between the groups is $180 / 37(=4.86)$. I will identify several phenomena where the proportion is lower or higher than this average. The quantitative reasoning is the following: if the proportion is lower, then there are relatively more "counterexamples" and probably the contrastive difference is less important and translator's decisions play a more important role; on the contrary, if the proportion is higher than average, then this phenomenon may "trigger" the translational shift and might reveal a dimension of the contrastive difference.

In Section 4, I will discuss several groups of translational shifts that do not seem to be primarily motivated by the overall contrastive difference, or at least show that other motivations can play a role. By starting the discussion with these examples, I would like to underline the fact that in translation there is more going on than contrasting two linguistic systems. After all, it is obvious that translators can choose not to use the structurally most congruent construction, or to render the semantic meaning in a different way, in order to achieve equivalence on a pragmatic, narratological or broader literary level.

Then, in Section 5, I will elaborate on the contrastive analysis of Dutch and Spanish DemNPs and DefNPs, relating the translational shifts with the two features of deictic and predicating force.

\section{Local translation decisions}

\subsection{Perceptual frame variation}

In this section, I will describe a phenomenon referred to as "perceptual frame variation". This means that the source text and the target text are not equivalent because in one of them there is more emphasis on a perceptual frame, i.e. the DemNP suggests that some instance (the narrative voice, or a character) perceives the discourse entity, whereas in the other text this discourse entity is referred to in a more neutral, descriptive way using a DefNP'. In (10) the Dutch DefNP het zinloze gordijn ('the unavailing curtain') is translated by the Spanish DemNP esa cortina sin sentido ('that unavailing curtain'). As we have pointed out, this shift is exceptional. However, the translational shift leads to an interpretive difference with the source text. In the Dutch ST, DefNP functions as an associative anaphor, 
which describes the new discourse referent the curtain as an element that the reader can identify thanks to its relation with a previously established referent, namely the ship's cabin. In the Spanish TT, however, the addition of ese portrays the curtain as something that is visually perceived from the viewpoint of the story's character (we are looking through the eyes of the passenger). This is a case of an intradiegetic deictic center, triggered by other contextual features, such as the mental verb in he knows what will happen then, or in the use of the future he will fall asleep, which is defined with regard to the temporal zero-point of the character (Genette 2007: 340). In the Spanish TT, this deictic center is reinforced by the use of the demonstrative, placing the curtain within the perceptual domain of the intradiegetic deictic center. Now, what I have described is not typical of Spanish, but it can also be achieved in Dutch (or English for that matter) by the same shift between DefNP and DemNP. In Dutch too, a DemNP is possible and its use would trigger the perceptual frame variation, and, by the same token, a DefNP is also possible in Spanish, except that then, the perceptual nuance would be lost.

NL Langzaam geeft hij zich gewonnen aan de deining van het schip, een grote moederdans, en hij weet hoe het verder zal gaan. In de loop van de nacht zal hij eindelijk inslapen, dan zal het eerste licht door het $\{\sim$ dat\} zinloze gordijn vallen, (Nooteboom, De omweg naar Santiago)

ES El viajero va entregándose lentamente al bamboleo del barco, un gran baile materno, y sabe lo que pasará después. En el transcurso de la noche se dormirá por fin, entonces entrará la primera luz a través de esa $\left\{\begin{array}{l}\text { la }\} \text { cortina } \\ \text { din }\end{array}\right.$ sin sentido, (Nooteboom, El desvío a Santiago)

'Gradually he surrenders to the roll of the ship, a big mother's dance, and he knows what will happen then. In the course of the night he will fall asleep at last, then the first light will stream in through $\left\{\right.$ the $_{\mathrm{NL}} \sim$ that $\left._{\mathrm{ES}}\right\}$ unavailing curtain'

In the next Example, the perceptual frame (triggered by other elements in the context, such as what I see or images) is less activated in the target text than in the source text. In the Dutch DemNP dat zwarte sap dat ... ('that black juice ...'), the use of Dem places the referent explicitly in the perceptual domain of the I-character, whereas Spanish DefNP el humor negro que ... ('the black juice...') describes the referent as something that can be identified on the basis of the descriptive content of the NP. Please note also that the present tenses in the Dutch DemNP (spuit ['squirt']; is ['is']) are translated by past tenses in Spanish (brotaba ['squirted'], era ['was']). In Dutch, the demonstrative form and the present tense interact in activating the deictic center, its perceptual and/or temporal grounding dimension, respectively.

(11) NL [de televisie] Wat ik zie is een deel van een serie: de geschiedenis van het stieregevecht. Beelden van een gevecht uit Mexico, 1916. [...] Toch was voor de stierenvechter het gevecht echt gevaarlijk, hij werd ècht gewond, en dat \{ het\} zwarte sap dat iets te snel uit zijn versierde kleding naar buiten spuit is echt bloed. (Nooteboom, De omweg naar Santiago)

ES [la televisión] Lo que veo es un capítulo de una serie: la historia de la tauromaquia. Imágenes de una corrida en México, en 1916. [...] Sin embargo, para el torero la lucha era realmente peligrosa, el toro lo cogió de verdad, y el \{ nese\} humor negro que brotaba -algo demasiado deprisa- de su traje decorado era sangre auténtica. (Nooteboom, El desvío a Santiago) 
'[television] What I see is part of a series: the history of the corrida. Images of a bullfight in Mexico, 1916. [...] Nonetheless, to the bullfighter the fight was truly dangerous, he was truly wounded, and $\left\{\right.$ that $_{\mathrm{NL}} \sim$ the $\left._{\mathrm{ES}}\right\}$ black juice squirting just a little too rapidly from his embroidered costume is real blood.'

As was the case in (10), also in Example (11), Dutch and Spanish allow both DefNP and DemNP, with the same meaning effects: DemNP activates a perceptual frame associated with an (intradiegetic) deictic center, whereas DefNP offers a description of the discourse entity.

In the corpus, 24 similar examples were identified (i.e. examples with an asymmetrical DemNP $\leftrightarrow$ DefNP pattern where a perceptual frame is activated or not, as the case may be). The question is whether these examples illustrate a general contrastive or translational trend or not. With regard to the contrastive analysis, the first thing to observe is that the discussion of the examples (see above) suggests that in these contexts the two paradigms function in a very similar way in both languages. From a quantitative perspective, it is true that more occurrences were identified with Dutch DemNP $\leftrightarrow$ Spanish DefNP (17) than with Spanish DemNP $\leftrightarrow$ Dutch DefNP (7), but this difference is less important than the average result (perceptual frame variation $17 / 7=2.43$; average 4.86). Hence, the mechanism of "perceptual frame variation" does not reinforce the overall difference between the two language systems.

The corpus data, however, does not point towards a systematic translation trend either. It is not the case that translations systematically emphasize the perceptual frame more (or less): in the subcorpus $\mathrm{NL} \rightarrow \mathrm{ES}$ the perceptual frame is more often weakened than strengthened in translation (12 vs. 5), whereas in the subcorpus ES $\rightarrow \mathrm{NL}$ the opposite trend can be found ( 2 vs. 5 ).

In sum, the phenomenon of "perceptual frame variation" does not reveal a systematic cross-linguistic difference, nor a systematic translational tendency. The translational shifts are presumably local decisions, and in this sense they might reveal interesting local deictic center shifts, and as such can be interpreted as traces of the translator's interpreting and recontextualization effort. As was claimed by Goethals \& De Wilde (2009), the search and the translational rendering of the deictic center clearly forms a constant threat to translators, and this difficulty can help explain the relatively high frequency of shifts in deictic expressions. It does not, however, allow to predict the form that the shifts will take: from demonstrative to definite or vice versa.

\subsection{Cultural embeddedness of anaphoric deictic links}

In this section, I will discuss a group of examples which show that the need to activate a deictic domain with a DemNP construction does not only depend on the linguistic systems, but also on the cultural setting. I will call this the "cultural embeddedness of anaphoric links". Let us consider Example (12), where Spanish DefNP la guerra de reconquista ("the war of reconquest') was translated by Dutch DemNP deze heroveringsoorlog ('this war of reconquest'). For a Spanish-speaking audience, the concept guerra de reconquista is culturally associated with the period of the Catholic Monarchs. This means that the cultural setting contributes to the unique identifiability of the concept. In Dutch, however, the concept heroveringsoorlog functions rather as a general description that is identified in a unique way through the anaphoric link with the preceding context: the DemNP deze heroveringsoorlog ('this war of reconquest') now functions as a categorizing concept of the previously described referent (Maes and Noordman 1995): 
ES Fernando de Aragón e Isabel de Castilla [...] abatieron a comienzos de 1492 el último reducto de la religión musulmana en suelo español. Había costado casi ocho siglos recobrar lo que se había perdido en siete años y la guerra de reconquista había agotado el tesoro real. (Galeano, Las venas abiertas)

NL Ferdinand van Aragón en Isabella van Castilië [...] vernietigden begin 1492 het laatste Arabische bolwerk op Spaanse bodem. Het had bijna acht eeuwen geduurd voordat weer veroverd was wat in zeven jaar verloren was en door deze heroveringsoorlog was de koninklijke schatkist leeg geraakt. (Galeano, De aderlating van een continent)

'Ferdinand of Aragón and Isabella of Castile [...] destroyed at the beginning of 1492 the last Arab bastion on Spanish soil. It had taken nearly eight centuries to win back what was lost in seven years, and $\left\{\right.$ the $_{\mathrm{ES}} \sim$ this $\left._{\mathrm{NL}}\right\}$ war of reconquest had drained the royal treasury.'

Also in Example (13) it is reasonable to assume that the unique identification of the referent of DefNP la colonia portuguesa de América ('the Portuguese Latin American colony') is easier for a Spanish-speaking audience, who are familiar with the colonial past of Latin-America, than for a Dutch-speaking audience, who could have more difficulty in identifying the referent solely on the basis of this description. The anaphoric link in Dutch DemNP deze Portugese kolonie in Zuid-Amerika ('this Portuguese Latin American colony') makes this coreference link self-evident.

(13) ES En cambio, hasta mediados del siglo XVII, Brasil fue el mayor productor mundial de azúcar. Simultáneamente, la colonia portuguesa de América era el principal mercado de esclavos; (Galeano, Las venas abiertas)

NL Brazilië daarentegen was tot halverwege de 17de eeuw de grootste suikerproducent ter wereld. Tegelijkertijd was deze Portugese kolonie in ZuidAmerika de belangrijkste slavenmarkt; (Galeano, De aderlating van een continent)

'Until the middle of the seventeenth century, Brazil, however, was the world's largest sugar producer. At the same time, $\left\{\right.$ the $_{\mathrm{ES}} \sim$ this $\left._{\mathrm{NL}}\right\}$ Portuguese Latin American colony was also the chief market for slaves;'

In Examples (12) and (13), a lesser degree of cultural embeddedness is compensated for by the activation of an anaphoric domain. However, it would be too bold to state that the cultural recontextualization that is inherent in translation necessarily leads to the replacement of DefNP by DemNP. Example (14) shows that also the opposite asymmetry can occur, particularly in cases where the anaphoric link itself is culturally grounded. In the Spanish ST, we find DemNP aquellas minas ('those mines'), which refers anaphorically to the relatively distant referent Zacatecas. In the Dutch TT, DefNP de mijnen ('the mines') is used. Presumably, the anaphoric link between aquellas minas and Zacatecas is more evident to the Spanish-speaking readership of the source text than it is to the readers of the Dutch target text. The latter presumably do not know that Zacatecas boasts an important mine industry, or have more difficulty in using this new information in the inferential interpretation of the anaphoric link. This is why Dutch DemNP die mijnen could complicate the interpretation and confuse the readers where the coreference relation is concerned. In the Dutch TT, DefNP de mijnen functions as an associative anaphor, and is interpreted as mines that apparently must be associated with the referent deze nu bloeiende provincie ('this presently flourishing province'). Strictly speaking, the coreference link with Zacatecas is no longer a prerequisite for a successful interpretation of the NP de mijnen. The interpretation frame is now the link 
with deze bloeiende provincie. It is interesting to note that the more prominent grounding role of this NP is reflected in another translational deictic shift, namely a shift from distal ese departamento ('that province') towards proximal deze provincie ('this province').

ES «Preciso es recurrir al fomento de la industria, como única fuente de una prosperidad universal -decía-. De nada serviría a Puebla la riqueza de Zacatecas, si no fuese por el consumo que proporciona a sus manufacturas, $y$ si éstas decayesen otra vez como antes ha sucedido, se arruinaría ese departamento ahora floreciente, sin que pudiese salvarlo de la miseria la riqueza de aquellas minas». (Galeano, Las venas abiertas)

NL 'Het is noodzakelijk om ons te richten op de opbouw van de industrie want dat is de enige bron van universele welvaart,' zei hij. 'De rijkdom van Zacatecas zou niets waard zijn voor Puebla als Puebla's producten hierdoor niet de gelegenheid kregen om geconsumeerd te worden, en als die producten weer zouden wegvallen, zoals vroeger gebeurd is, zal deze nu bloeiende provincie te gronde gaan zonder dat de rijkdom van de mijnen haar kan redden.' (Galeano, De aderlating van een continent)

"We must proceed to develop industry as the only source of general prosperity," he said. "The wealth of Zacatecas would bring no benefits to Puebla but for the consumption that it brings to its manufactures, and if these decline again, as has happened before, that presently flourishing province will be ruined and the wealth of $\left\{\right.$ those $_{\mathrm{ES}} \sim$ the $\left.\underline{\mathrm{NL}}_{\mathbf{N}}\right\}$ mines will not be able to save it from poverty."

In the corpus, I found 9 similar examples with the pattern Dutch DemNP $\leftrightarrow$ Spanish DefNP and 2 examples in the group Spanish DemNP $\leftrightarrow$ Dutch DefNP. Although the proportion represents about average (4.5 vs. 4.86), the qualitative discussion makes it clear that the shifts should not be interpreted as purely linguistic phenomena. There is a broader phenomenon at work, namely the cultural embeddedness of referent and anaphoric link identification, which interferes with the cultural re-contextualization of the translation process. Yet, it is problematic to see this translation phenomenon as an explanatory factor for the quantitative data outlined in Section 2, and especially for the observation that Dutch DemNPs frequently correspond to Spanish DefNPs, because a lesser degree of cultural embeddedness may lead both to the introduction and the substitution of a Dem form.

\subsection{More special cases: non-equivalent translations, and constructional shifts}

I will proceed to discuss two additional types of examples in order to illustrate that in empirical corpus translation studies examples are extremely varied, and often reveal a complex interplay of competing motivations and decisions. This is a necessary methodological backdrop before we proceed to the contrastive analysis on the basis of translational data.

In (15), the exceptional shift Spanish DemNP $\leftrightarrow$ Dutch DefNP modifies the interpretation of the sentence: in the Dutch ST, the DefNP de bedoeling ('the purpose') conveys the idea that there is such a thing as an inherent unique purpose of terrestrial life (given the contextual cues, the reader will infer that this must be procreation). The Spanish DemNP esta finalidad ('this purpose') does not evoke the same idea of inherent uniqueness, because the uniqueness of the referent is achieved through the anaphoric link. 
(15) NL De twee kevers scharrelden wat over elkaar heen alsof het een opdracht was, wat natuurlijk ook zo is. Wij zijn de enige soort die van de bedoeling is afgedwaald (Nooteboom, Het volgende verhaal)

ES Los dos escarabajos trastearon un poco el uno sobre el otro como si fuera un mandato, que desde luego lo es. Somos la única especie que se ha desviado de esta finalidad (Nooteboom, La historia siguiente)

'The two beetles scurried around to get on top of each other as if it was a task, which of course it was. We are the only species that has strayed from $\left\{\right.$ the $_{\mathrm{NL}} \sim$ this $\underline{E S}$ ? purpose.'

Example (16) is one more case of the atypical pattern Spanish DemNP $\leftrightarrow$ Dutch DefNP. This shift is part of a broader constructional shift, since the translator uses a more specific term than in the source text ('Inca terraces' vs. 'terraces'). Since the NP is more specific, it is no longer necessary to activate an anaphoric domain to restrict the reference.

ES Aunque las gigantescas obras públicas de los incas fueron, en su mayor parte, borradas por el tiempo [...], restan aún [...] las interminables terrazas [...]. Un técnico norteamericano estimaba, en 1936, que si en ese año se hubieran construido, con métodos modernos, esas terrazas, hubieran costado unos treinta mil dólares por acre. (Galeano, Las venas abiertas)

NL Hoewel de reusachtige openbare werken van de Inca's voor het grootste gedeelte weggevaagd zijn door de tijd [...], zijn de eindeloze terrassen [...]. Een Noord-Amerikaanse expert heeft in 1936 uitgerekend dat als de Incaterrassen dat jaar aangelegd zouden worden met moderne methodes, dit zo'n 30.000 dollar per acre zou kosten. (Galeano, De aderlating van een continent)

'Although the Incas' great public works were for the most part destroyed by time [...], there still are [...] the endless terraces [...]. A U.S. technician estimated in 1936 that if \{those terraces $\mathrm{ES}_{\mathrm{ES}} \sim$ the Inca terraces $\left.{ }_{\mathrm{NL}}\right\}$ had been built by modern methods in 1936, they would have cost some $\$ 30,000$ per acre.'

Example (17) is very similar to (16), but now Dutch is the source language. Again, the translator uses a more specific term ('Sunday' instead of 'day'), and therefore substitutes DemNP by DefNP. In Examples (16) and (17), the DemNP $\leftrightarrow$ DefNP asymmetry is a "collateral effect" of an explicitation strategy in translation.

$$
\begin{aligned}
& \text { NL [ze] benutte die dag om uit te rusten (de Vries, Medeplichtig) } \\
& \text { ES prefería descansar el domingo (de Vries, Cómplice) } \\
& \text { 'She preferred to rest on }\left\{\text { that day }{ }_{\mathrm{NL}} \sim \text { Sunday }_{\underline{E S}}\right\} \text { ' }
\end{aligned}
$$

In the corpus, 19 similar examples were identified: 11 with the pattern Dutch DemNP $\leftrightarrow$ Spanish DefNP and 8 with the pattern Spanish DemNP $\leftrightarrow$ Dutch DefNP. The proportion between the two groups is 1.38 , which is clearly lower than the average proportion (4.86).

In this section, I have discussed several DemNP $\leftrightarrow$ DefNP shifts: variations in the emphasis on a perceptual frame, shifts that are related to a different cultural embeddedness of the anaphoric relations, semantically non-equivalent translations and constructional shifts. I would like to argue that these shifts are not primarily motivated by a contrastive linguistic difference in the constructional meaning of DefNP and DemNP in Dutch and Spanish. The first reason is that the qualitative description of the examples does not clearly favor one or 
another form. Rather, the description suggests that the shift can occur in both translation directions. The second argument is that, in the corpus, these phenomena are not only found in the group of examples that display the most frequent pattern Dutch DemNP $\leftrightarrow$ Spanish DefNP (37), but also in the group of examples with the "exceptional" pattern Spanish DemNP $\leftrightarrow$ Dutch DefNP (17). The proportion between the two groups is 2.17 , which is significantly lower than the average proportion of 4.86 (p-value 0.003 ). This means that a relatively high number of exceptional examples can be explained by phenomena that are primarily translation- or translator-related. In other words, it supports the hypothesis that the overall quantitative trend discussed in Section 3 reveals a linguistic difference between Spanish and Dutch. $^{8}$

In the sections that follow, however, I will focus on several groups of examples that seem far more typical of the Dutch DemNP $\leftrightarrow$ Spanish DefNP pattern. Based on a qualitative analysis, I will attempt to prove that these translational shifts reveal differences in the constructional meaning of DemNP and DefNP in Dutch and Spanish.

\section{Translational shifts and the constructional meaning of DemNP and DefNP in Dutch and Spanish}

Having described a few translation-related phenomena, we can now proceed to the contrastive analysis of Spanish and Dutch DemNPs and DefNPs, thereby focusing on several groups of examples that fit the frequent pattern Dutch DemNP $\leftrightarrow$ Spanish DefNP. As was shown in Section 3, this pattern is found independently of the translation direction and, thus, the hypothesis is that it reveals a contrastive difference.

Taking into account the constructional meaning of DemNP and DefNP as outlined in Section 1, four situations can explain the asymmetry between Dutch DemNP and Spanish DefNP:

\begin{tabular}{|l|l|l|}
\hline & \multicolumn{1}{|c|}{ Dutch DefNP } & \multicolumn{1}{c|}{ Spanish DemNP } \\
\hline deictic force & $\begin{array}{l}\text { "compared to Spanish DefNP, } \\
\text { Dutch DefNP lacks deictic force; } \\
\text { therefore, Dutch DemNP is used" }\end{array}$ & $\begin{array}{l}\text { "compared to Dutch DemNP, Spanish } \\
\text { DemP has too much deictic force; } \\
\text { therefore Spanish DefNP is used" }\end{array}$ \\
\hline $\begin{array}{l}\text { predicating } \\
\text { force }\end{array}$ & $\begin{array}{l}\text { "compared to Spanish DefNP, } \\
\text { Dutch DefNP lacks predicating } \\
\text { force; therefore Dutch DemNP is } \\
\text { used" }\end{array}$ & $\begin{array}{l}\text { DemNP has to Dutch DemNP, Spanish } \\
\text { force; therefore Spanish DefNP is } \\
\text { used" }\end{array}$ \\
\hline
\end{tabular}

\subsection{Dutch DefNPs lack deictic force}

The first type of contexts consists of examples where the Spanish DefNP seems to display more deictic force than its Dutch counterpart. This occurs in contexts that require a determiner with sufficient deictic force, for example when the (co)referential link between the $\mathrm{NP}$ and its referent is not self-evident. I will give examples of several types of anaphors and discourse deictics.

Example (18) illustrates a hyperonymic anaphoric relation with a nominal antecedent. In the Spanish source text, DefNP el negocio ('the business') is interpreted as a hyperonym that is coreferential with the concept la compra y venta de carne humana ('buying and selling human flesh') in the previous sentence, and thus does not mean business in general, but rather this type of business, namely slave trade. In Dutch, the use of DefNP would complicate this interpretation in that the reader would have some difficulty in interpreting de handel as a 
hyperonym for this type of business, and not as the generic concept (to convey the same generic meaning, English would probably use a bare NP). The use of DemNP makes this anaphoric link self-evident.

(18) ES Inglaterra fue, hasta que ya no le resultó conveniente, la gran campeona de la compra y venta de carne humana. Los holandeses tenían, sin embargo, más larga tradición en el negocio, , (Galeano, Las venas abiertas)

$N L \quad$ Engeland was tot het moment dat het haar niet langer uitkwam de grote kampioene van de in- en verkoop van mensenvlees. Maar de Hollanders hadden een langere traditie in deze $e_{i}$ de ? $\}$ handel. (Galeano, De aderlating van een continent)

'England was, until it was no longer convenient for them, the big champion in buying and selling human flesh. The Dutch, however, had longer experience in the $_{\mathrm{ES}} \sim$ thiS $\left._{\mathrm{NL}}\right\}$ business.'

Among the examples with a Dutch DemNP $\leftrightarrow$ Spanish DefNP asymmetry, there are 12 similar examples of hyperonymic anaphors with a nominal antecedent. However, there is only one "counterexample" that shows the Spanish DemNP $\leftrightarrow$ Dutch DefNP asymmetry. This data suggests that Spanish DefNP has more deictic force than its Dutch counterpart, in the sense that it still seems to activate the anaphoric deictic domain, favoring a hyperonymic over a generic interpretation of the NP. To achieve the same effect, Dutch uses a DemNP more frequently.

The next example is a different type of non-evident anaphoric link with a nominal antecedent. In (19), the NP is a metaphoric description of the antecedent. Apparently, in the Spanish source text, DefNP is still sufficiently deictic to show the reader the anaphoric link with the antecedent. This seems less evident in Dutch: the reader could have serious doubts about what is meant by het blonde gordijn ('the blonde curtain'). Again, the use of DemNP makes the coreference interpretation self-evident.

(19) ES al inclinar el rostro, el cabello se le había deslizado sobre la cara; tras la $_{i}$ cortina rubia observaba a su visitante con suspicacia (Pérez Reverte, El Club Dumas)

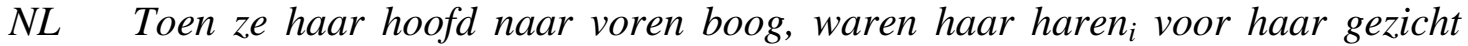

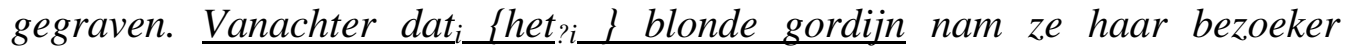
argwanend op. (Pérez Reverte, De Club Dumas)

'When she tilted her face, her hair had crept over her face; behind $\left\{\right.$ the $\underline{E S}_{-}$ that ${ }_{N L}$ blonde curtain she watched the visitor with suspicion'

Example (20) is similar to (19), except that the link is metonymic: the DefNP la industria does not mean industry in general in this context, but rather the industry of producing chocolate. So, there is a coreference relationship between la industria and el chocolate but this is not a straightforward coreference relation, since both concepts do not mean the same thing, but are related metonymically (product - specific production industry). In Dutch, with DefNP de industrie, it is doubtful whether the reader would be able to readily establish this metonymic link, but with DemNP the anaphoric relation is guaranteed:

ES En las últimas décadas del siglo XIX se desató la glotonería de los europeos y los norteamericanos por el chocolate ${ }_{i}$. El progreso de la industria ${ }_{i}$ dio un gran impulso a las plantaciones de cacao en Brasil (Galeano, Las venas abiertas) 
NL In de laatste decennia van de 19de eeuw brak bij de Europeanen en de Noord-

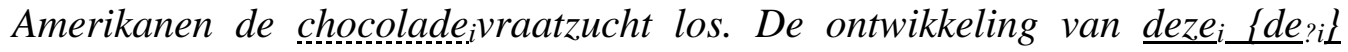
industrie was een grote stimulans voor de cacaoplantages in Brazilië. (Galeano, De aderlating van een continent)

'The last decades of the nineteenth century saw the start of Europe's and the U.S.'s gluttony for chocolate. The development of $\left\{\right.$ the $_{\mathrm{ES}} \sim$ this $\left.{ }_{\mathrm{NL}}\right\}$ industry gave a boost to Brazilian cacao plantations.'

Obviously, these types of metaphoric and metonymicanaphoric links are not frequent, but it is interesting to note that all asymmetric examples (four to be precise) match the pattern Dutch DemNP $\leftrightarrow$ Spanish DefNP. There were no examples with the pattern Spanish DemNP $\leftrightarrow$ Dutch DefNP.

Let us now consider anaphors that establish a coreference relation between the NP and a prior description that exceeds the boundaries of an NP, i.e. a clause, a proposition or even a sequence of propositions (called complex anaphora in Consten, Knees and Scharz-Friesel 2007). In total, we find in the corpus 30 such anaphors with an asymmetric DemNP $\leftrightarrow$ DefNP pattern: 27 with the pattern Dutch DemNP $\leftrightarrow$ Spanish DefNP and 3 with the pattern Spanish DemNP $\leftrightarrow$ Dutch DefNP (proportion 9, vs. average 4.86). For example, in (21) el gesto ('the gesture') refers to the action of levantar el vaso ('raise the glass'). The Spanish DefNP is translated by Dutch DemNP die beweging ('that gesture'), and, indeed, it seems counterintuitive to use DefNP ('de beweging') in this context because it makes the coreference relation unnecessarily complex to process.

(21) ES Makarova se había acercado por el otro lado de la barra [...]. La Ponte, a

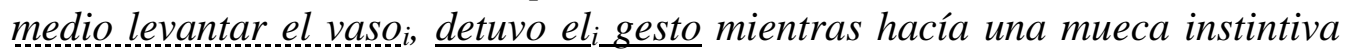
de avidez profesional. (Pérez Reverte, El Club Dumas)

NL Makarova was achter de bar naar hen toe gekomen [...]. La Ponte, die zijn glas half omhoog had geheven , verstarde in die $_{i}$ _de ? I beweging terwijl een instinctmatig trekje van beroepsmatige hebzucht op zijn gezicht verscheen. (Pérez Reverte, De Club Dumas)

'Makarova had come closer by the other side of the bar [...]. La Ponte, holding the glass half-raised, stopped $\left\{\right.$ the $_{\mathrm{ES}} \sim$ that $\left._{\mathrm{NL}}\right\}$ gesture while she winced instinctively with professional greed.'

(22) and (23) are two similar examples of indirect anaphors. In both examples, a Dutch DemNP is used to translate a Spanish DefNP. Although it is grammatically possible to use the DefNP construction without causing a referential misinterpretation of the NP, it seems counterintuitive to use it because of the less smooth coreference link:

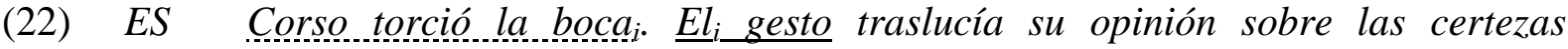
absolutas en bibliofilia: (Pérez Reverte, El Club Dumas)

NL Corso trok een scheef mondje . Met dat $_{i}$ Shet $_{i}$ L gebaar gaf hij blijk van wat hij over absolute zekerheden op bibliofiel gebied dacht: (Pérez Reverte, De Club Dumas)

'Corso twitched his mouth. $\left\{\right.$ The $\left._{\mathrm{ES}} \sim \mathrm{That}_{\mathrm{NL}}\right\}$ gesture revealed his views on the absolute certainties in bibliophilia'

(23) ES El presidente Getulio Vargas se había partido el corazón de un balazoi, en 1954, y la cotización del café no había sido ajena a la i tragedia: (Galeano, Las venas abiertas) 
NL President Getulio Vargas had zich in 1954 een kogel door het hart geschoten en de koffiekoers had alles te maken met $\underline{\text { die }}_{i}\left\{\right.$ de $\left.{ }_{\text {?i }}\right\}$ tragedie: (Galeano, De aderlating van een continent)

'President Getulio Vargas put a bullet through his heart in 1954, and the price of coffee played a role in $\left\{\right.$ the $\underline{E S}_{2} \sim$ that $\left.{ }_{\mathrm{NL}}\right\}$ tragedy:'

The group of discourse deictics also illustrates the idea that Spanish DefNPs can be used more easily than Dutch DefNPs to establish non-evident links between the NP and the context. In (24), the DefNP el sarcasmo ('the sarcasm' - 'the sarcastic comment') refers to the speech act that was realized in the previous sentence. Although in Dutch, DefNP is not impossible, it would be surprising because the discourse deictic link seems rather difficult, or at least more difficult to establish than in Spanish.

ES - Tal vez se enfrente a ciertas complicaciones...

- No me diga.

Tras el sarcasmo , oyó al librero aclararse la garganta. (Pérez Reverte, El Club Dumas)

NL 'Misschien kom je voor zekere complicaties te staan...'

'Je meent het $t_{i: .}$

Na die $\underline{i}_{i}\left\{\right.$ de $\left._{\text {? }}\right\}$ sarcastische opmerking hoorde hij de boekhandelaar zijn keel schrapen. (Pérez Reverte, De Club Dumas)

'- You may be facing some complications ...

- You must be kidding.

- After $\left\{\right.$ the $_{\mathrm{ES}} \sim$ that $\left._{\mathrm{NL}}\right\}$ sarcastic comment, he heard the bookseller clearing his throat'

In the corpus, we found ten similar discourse deictic examples with the pattern Dutch DemNP $\leftrightarrow$ Spanish DefNP. There are also three counterexamples, though, with the pattern Spanish DemNP $\leftrightarrow$ Dutch DefNP, all with the marked distal form aquel (25). The reason to introduce aquel in the Spanish translation here may have more to do with a strategy to emphasize the marked temporal distance of the speech act than with the establishment of the referential link between the NP and the previous context. At least, the interpretation of DefNP la pregunta does not seem more difficult than is the case with aquella pregunta:

NL 'Enje ouders dan? Deden die ook niks? ?'.

Terwijl ze de vraag $_{i}$ stelde, besefte ze ineens hoe weinig ze van haar grootouders afwist, ze had hen ook nooit gekend. (de Vries, Medeplichtig)

ES - ¿Y tus padres? ¿No hicieron nada?

De repente, al formular aquella $\underline{i}_{\{}$la $\left._{i}\right\}$ pregunta, Marcelle cayó en la cuenta de que sabía poquísimo de sus abuelos; ni siquiera llegó a conocerlos. (de Vries, Cómplice)

"And your parents? They did not do anything either? "

As she asked $\left\{\right.$ the $_{\mathrm{NL}} \sim$ that $\left._{\mathrm{ES}}\right\}$ question, she suddenly realized how little she knew about her grandparents, for she had never known them.'

\subsection{Spanish DemNPs are "too deictic"}

Thus far, I have focused on examples in which Dutch DefNPs appear less adequate than Spanish DefNPs. I would now like to turn to the other end of the spectrum, namely contexts 
that require little deictic force and in which the asymmetry Dutch DemNP $\leftrightarrow$ Spanish DefNP seems to be attributed to the (overly) strong deictic force of Spanish DemNP.

A typical context is direct anaphors where the antecedent (or part thereof) is repeated verbatim. In contrast to the non-evident hyperonymic, metaphoric and metonymic anaphoric links discussed in Section 4.1, these contexts require little deictic force to establish the coreference link: the literal repetition of the antecedent more or less guarantees this link. Interestingly, this is also a typical context of Dutch DemNP $\leftrightarrow$ Spanish DefNP asymmetry: in the corpus, there are 35 examples in this group, and none in the group with the opposite asymmetry. Consider (26): the antecedent de titel van graaf ... ('the title of Count ...') is partially repeated in the DemNP die titel ('that title'). In the Spanish translation, however, a DefNP is used: el título ('the title').

(26) NL In 1453 werd don Alvaro de Luna [...] de titel verleend van graaf de San Esteban de Gormaz. Die titel bestaat nog steeds [...] (Nooteboom, De omweg naar Santiago)

ES En 1453 se le otorgó a don Alvaro de Luna [...] el título de Conde de San Esteban de Gormaz. El título existe todavía [...] (Nooteboom, El desvío a Santiago)

'In 1453 Don Alvaro de Luna [...] was given the title of Count of San Esteban

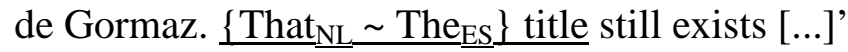

The factor that could explain this clear trend in the translational data seems less related to the Dutch DefNP as it is to the Spanish DemNP constructions: although the latter form is grammatically possible, it is perceived as strongly marked.

A subgroup of these examples consists of six almost identical translational shifts in one of the texts in the corpus. As Examples (27-29) show, DemNP die jachtopziener ('that game warden') is consistently translated by DefNP el guardabosque. It is important to know that the main story line is about the murder of a game warden, for which three boys have been convicted in the past. A letter has shown up that says that the boys were innocent. The three central items the game warden, the boys and the letter are constantly repeated throughout the story (for example, the NP die/de jachtopziener occurs 65 times in the book from which the corpus sample was taken). In the entire Dutch source text, a DemNP is used in 15 references to the game warden. Interestingly, these cases are all translated in Spanish by DefNP. ${ }^{9}$ In (28), the same shift can be observed in the reference to the three boys.

NL 'In het dorp heeft iedereen zijn mond vol over die jachtopziener van Bidernais.' (de Vries, Medeplichtig)

ES Todos en el pueblo hablan del guardabosque de Bidernais. (de Vries, Cómplice)

'In the village everyone is talking about $\left\{\right.$ that $_{\mathrm{NL}} \sim$ the $\left._{\mathrm{ES}}\right\}$ game warden of Bidernais'

(28) NL 'Niet zozeer over die jachtopziener zelf, maar over die jongens die zijn gegrepen. (de Vries, Medeplichtig)

ES Bueno, más que sobre el guardabosque hablan de los muchachos condenados. (de Vries, Cómplice)

'They speak not so much about $\left\{\right.$ that $_{\mathrm{NL}} \sim$ the $\left._{\mathrm{ES}}\right\}$ game warden himself, but about $\left\{\right.$ those $_{\mathrm{NL}} \sim$ the $\left.\mathrm{ES}_{\mathrm{ES}}\right\}$ boys who are captured.'

(29) NL Je was toch met die jachtopziener verloofd? (de Vries, Medeplichtig)

ES Tú eras la novia del guardabosque? (de Vries, Cómplice)

'You were the girlfriend of $\left\{\right.$ that $_{\mathrm{NL}} \sim$ the $\left.\mathrm{ES}\right\}$ game warden, weren't you?' 
My hypothesis is that the systematic translational shift is due to the fact that it is not critical to activate a deictic domain in which the referent is to be identified. Since the referents are the key topics of the story, their identification is quite obvious. In Dutch, the conflict between the DemNP construction and the already prominent status of the referents seems to be less rigorous than in Spanish: in Spanish, DemNP seems to suggest that the referent needs a relatively strong device to be identified, or to regain its prominent status. In this sense, a Dutch DemNP can also express a more bleached form of deictic force, which would consist of evoking the overall narrative frame in which the referent is situated. The data suggests that a Spanish DemNP is more often felt to be too strong in these contexts.

Thus far, I have argued that Dutch DefNPs and DemNPs have less deictic force than their respective Spanish counterparts. This explains why Dutch DefNP seems less adequate than Spanish DefNP in contexts that require a relatively high degree of deictic force in order to identify the referent of the NP. And it also explains why Spanish DemNPs seem less adequate than Dutch DemNPs in contexts that require a low deictic force to identify the referent. In the following subsections, I will apply the same reasoning to the other distinguishing feature, namely the predicating force of the NP.

\subsection{Dutch DefNPs lack predicating force}

As was explained in Section 2, the second distinguishing feature of the DemNP construction is that the NP is not primarily assigned an identifying function (this identification can occur within the deictic domain) and thus acquires predicating force. The difference between DemNP and DefNP consists then in a downgrading of the predicating force of the NP. I maintain that Dutch DefNPs seem to have lost their "original predicating force" to a higher degree than their Spanish counterparts. Consider (30) as a case in point: in Spanish, a clearly subjective qualification is introduced in the DefNP los gringos pendejos ('the stupid gringos'), enriching the generic constructional meaning of DefNP that does not necessarily assign predicating force to the NP. In the Dutch translation, the Spanish DefNP is changed into a DemNP, and, indeed, a DefNP de klotegringo's ('the stupid gringos') would conflict with the subjective, predicating nature of the NP. If a DefNP is used in Dutch, the NP seems to be a more or less conventional way of identifying the referent, and not a subjective evaluation on behalf of the speaker.

$$
\begin{aligned}
& \text { ES [entonces] no habría sanciones y los gringos pendejos no joderían con la } \\
& \text { soberanía (Vargas Llosa, La fiesta del Chivo) } \\
& \text { NL } \\
& \text { [dan] zouden er geen sancties zijn en zouden die \{?de\} klotegringo's niet zitten } \\
& \text { te zeiken over soevereiniteit (Vargas Llosa, Het feest van de Bok) } \\
& \text { '[then] there would be no sanctions and }\left\{\text { the } \underline{E S}_{\text {LS }} \sim\right. \text { those } \\
& \text { not be whining about sovereignty' stupid gringos would }
\end{aligned}
$$

Apparently, Spanish DefNPs give more room for such qualifications than Dutch DefNPs: in the corpus, there are 22 similar examples with the Dutch DemNP $\leftrightarrow$ Spanish DefNP asymmetry and only one case with the pattern Spanish DemNP $\leftrightarrow$ Dutch DefNP. This clearly shows that the predicating character of the NP may trigger the translational shift. Example (31) illustrates the same phenomenon:

ES Olvidas que esas pendejadas no las escribiste tú, que no sabes escribir tu nombre sin faltas gramaticales, sino el gallego traidor de José Almoina, (Vargas Llosa, La fiesta del chivo) 
NL 'je vergeet dat niet jij die flauwekul hebt geschreven, want jij kunt nog niet eens je naam foutloos spellen, maar die \{?de\} verraderlijke Galliciër José Almoina, (Vargas Llosa, Het feest van de Bok)

'You forget that you did not write those stupid things, you don't even know how to spell your name without grammatical errors, but the ES $_{2}$ that $\left._{\mathrm{NL}}\right\}$ Galician traitor José Almoina'

Examples (30-31) are cases of recognitional demonstratives, and refer to an entity that is supposed to be familiar to the addressee. Example (32), however, is a clear anaphor with a nominal antecedent. It illustrates that predicating force is also relevant here: the narrator describes a scene wherein a teacher re-enacts Socrates' suicide. The first sentence refers to the cup, as if it were a real cup, but the referent is then redefined as an imaginary cup in the DemNP die niet-bestaande beker ('that non-existing cup'). To achieve this dynamic reclassification, Dutch seems to need the DemNP construction: DefNP de niet-bestaande beker ('the non-existing cup') would suggest that the reader is already well aware of the fact that it is a non-existing cup. In Spanish, however, the identificational meaning of the DefNP construction is more easily enriched, in this case by introducing an evaluative adjective in prenominal position (la ilusoria copa):

(32) NL En hij geeft me de beker, en ik drink hem langzaam leeg en als ik die \{?de\} niet-bestaande beker tot het laatst heb leeggedronken ... (Nooteboom, Het volgende verhaal)

ES Y Y me da la copa, y la vacío despacio y cuando he vaciado la ilusoria copa hasta el fin ... (Nooteboom, La historia siguiente)

'And he gives me the cup, and I drink it slowly and when I emptied that $_{\mathrm{NL}} \sim$ $\underline{\text { the }}_{\mathrm{ES}}$ \} non-existing cup to the last drop'

\subsection{Spanish DemNPs have too much predicating force}

In the last group of Dutch DemNP $\leftrightarrow$ Spanish DefNP shifts that I will consider, it seems difficult to use the Spanish DemNP construction when the NP has a purely identifying function. Dutch DemNPs seem to be more tolerant in this respect. This analysis might account for a recurrent pattern of shifts as illustrated in (33) and (34). In these contexts, the NP anderen ('others') is clearly identificational in the sense that it does not give any type of information about the referent. The referents are identified as the remaining members of a previously defined category. As we see in (33) and (34), Dutch DemNP can be combined with this type of NP, but in the Spanish translation a DefNP is used. Indeed, the use of a Spanish DemNP is counterintuitive, and very strongly marked:

(33) NL 'Hoe zou ze zijn? Ik hoop niet zoals die anderen.' (de Vries, Medeplichtig)

ES - ¿Cómo será? Espero que no sea como las \{? esas\} otras. (de Vries, Cómplice) 'How would she be? I hope she is not like $\left\{\right.$ those ${ }_{\mathrm{NL}} \sim$ the $\left._{\mathrm{ES}}\right\}$ others.'

(34) NL Er zitten er twintig of meer, en er staat er maar één, en de kennis van die ene staande moet in de nog onbeschreven hersens van al die anderen. (Nooteboom, Het volgende verhaal)

ES Hay veinte o más personas sentadas y sólo una está de pie, y el conocimiento de esa única persona que está de pie debe entrar en los cerebros todavía en blanco de todas las \{*esas\} demás. (Nooteboom, La historia siguiente) 
'Twenty or more people are sitting down, just one stands; and the knowledge of that one person on his feet must be transmitted to the still empty brains of all those $_{\mathrm{NL}} \sim$ the $\left._{\mathrm{ES}}\right\}$ others.'

Interestingly, the restriction on the use of a Spanish DemNP is stronger with demás (ex. 34) than with otros (ex. 33). The difference between the two elements is that demás is more exclusively identificational: it only refers to the remaining members of the category, whereas the meaning of otros can also express the nuance of "being different" (NGRAE 2009: Section 13.10w).

In the corpus, seven similar examples were identified, all of them belonging to the group of Dutch DemNP $\leftrightarrow$ Spanish DefNP.

\section{Conclusion}

In the present paper, I have tried to show that the use of a corpus of translated texts may help to understand and describe subtle cross-linguistic differences. The quantitative analysis of translational shifts reveals an asymmetry between the paradigms DefNP and DemNP in Dutch and Spanish. Specifically, it shows that in an important number of examples, Dutch DemNPs are translated by, or are used to translate Spanish DefNPs. However, the quantitative data do not offer a ready-made interpretation of the contrastive difference: are the translational shifts due to an asymmetry between Spanish and Dutch DemNP constructions, or to an asymmetry between Spanish and Dutch DefNP constructions, or to a combination of both? On the basis of the corpus results, I would argue that it is indeed a combination of both. Both Dutch DemNP and DefNP seem to be further semantically bleached and hence more grammaticalized than their Spanish counterparts.

I have described the specific constructional meaning of DemNP and DefNP by means of two distinguishing features, namely deictic force, and predicating force. These are relative values, which can be present at a high degree (the prototypical DemNP pole) or at a low degree (the prototypical DefNP pole). The examples have shown that recurrent patterns of translational shifts between Dutch DemNPs and Spanish DefNPs can be related to these constructional meaning dimensions. The frequent asymmetric situation of Dutch DemNP $\leftrightarrow$ Spanish DefNP particularly arises in contexts where a Dutch DefNP does not have enough deictic or predicating force (compared to a Spanish DefNP), and also in contexts where a Spanish DemNP has too much deictic or predicating force (compared to a Dutch DemNP).

Methodologically, this paper argues in favor of integrating bidirectional translational data into cross-linguistic analysis. The study of translational shifts is a powerful heuristic tool to identify rich data that can help us define and better understand subtle cross-linguistic differences. Particularly, the use of a bidirectional corpus allows to distinguish between the effect of contrastive linguistic differences and the effect of translator's decisions. Although several translation-related shifts were identified, such as shifts motivated by perceptual frame variation, or by the cultural embeddedness of anaphoric relations, they cannot explain the systematic quantitative trend of translating Dutch DemNPs by Spanish DefNPs (in the corpus $\mathrm{NL} \rightarrow \mathrm{ES}$ ) or of using Dutch DemNPs to translate Spanish DefNPs (in the corpus ES $\rightarrow \mathrm{NL}$ ). On the contrary: this trend reveals a cross-linguistic difference between Dutch and Spanish.

\section{Appendix: Corpus}

$\mathrm{NL} \rightarrow \mathrm{ES}$

de Vries, Anke. 1984. Medeplichtig. Lemniscaat. (Sample: 19.984 words) 
de Vries, Anke. 1991. Cómplice. Translated by M. Monteagudo Romero \& M. García Sendón. 1991.

Nooteboom, Cees. 1991. Het volgende verhaal. De Arbeiderspers. (Sample: 19.747 words)

Nooteboom, Cees. 1992. La historia siguiente. Translated by J. Grande. Siruela.

Nooteboom, Cees. 1992. De omweg naar Santiago. Atlas. (Sample: 17.314 words)

Nooteboom, Cees. 1995. El desvío a Santiago. Translated by J. Grande. Siruela.

$\mathrm{ES} \rightarrow \mathrm{NL}$

Galeano, Eduardo. 1981. Las venas abiertas. Siglo Veintiuno. (Sample: 42.332 words)

Galeano, Eduardo. 1991. De aderlating van een continent. Translated by M. Sabarte

Belacortu. Van Gennep/Novib.

Pérez Reverte, Arturo. 1993. El Club Dumas. Alfaguara. (Sample: 24.294 words)

Pérez Reverte, Arturo. 1995. De Club Dumas. Translated by J. Schalekamp. De Prom.

Vargas Llosa, Mario. 2000. La fiesta del Chivo. Alfaguara. (Sample: 20.661 words)

Vargas Llosa, Mario. 2001. Het feest van de Bok. Translated by A. van der Wal. Meulenhoff.

1 Following the new reference grammar for Spanish (NGRAE 2009), I use curly brackets and a tilde to present alternative constructions in invented examples. In the corpus examples, the original formulation is presented outside the brackets, and the forms that were added inside the brackets. In the translation examples from the corpus, first the source text is quoted, followed by the target text and an English translation. The English translation follows the source text as closely as possible, but reflects also the translational shifts that affect the DemNP or DefNP constructions. It presents these shifts between curly brackets, indicating in subscript the source of the alternative. For example, $\left\{\right.$ the $\left._{E S} \sim t_{\text {that }}\right\}$ ashtray means that in the Spanish text a DefNP is used and in Dutch a DemNP.

2 In fact, this example also illustrates the methodological complexity of analyzing demonstratives (see section 2). The Dem-form indeed gives an agrammatical result if we want to convey the meaning of an associative anaphor. However, if we say that the speaker is in the kitchen when he utters this sentence, then "Les gustó mucho esta cocina" is possible, because it would evoke the deictic domain of the speaker in the kitchen. Even "Les gustó mucho esa cocina" is possible if we take into account the possibility of a deictic center shift, especially in literary texts (see also section 3). The deictic center shift would imply that we see the scene through the eyes of the parents, or that we hear the parents speak; see also García Fajardo 2006, and Goethals \& De Wilde 2009 on the role of deictic center shifts in translation.

${ }^{3}$ In this paper I will only focus on the cross-linguistic shifts between the paradigms Def NP and Dem NP, leaving aside other differences such as the alternation between bare NPs and Def NPs. For example, the generic meaning of (6) would be translated into English with a bare NP (conducive to literature instead of conducive to the literature). In Dutch, both forms can convey a generic meaning (gunstig voor literatuur / gunstig voor de literatuur).

4 Although it is beyond the scope of this paper to give a full overview of the very extensive literature on demonstratives, it is worth noting that other authors in other traditions have made similar observations. In the French tradition, Kleiber 1986 referred to the "token-reflexive" nature of demonstratives, which means that the identification of the referent is not a neutral process, because the mental representation of the referent is modified by the description that is given in the DemNP in the host sentence, i.e. by the token. In the Spanish tradition, NGRAE (2009: Section 17.4c) describes the NP in DemNP as an 'appositional' or 'non-restrictive' element. To avoid conceptual and terminological confusion, I will use the terminology proposed by Maes and Noordman 1995.

5 The corpus consists of Spanish and Dutch essayistic and literary texts and their translations (literary and essayistic texts are, in fact, the only text types that are translated in a sufficient number in both translation directions). This electronic corpus was developed at the Faculty of Translation Studies of the Ghent University School. The total number of words is over 1,5 million, but, given the frequency of the demonstrative paradigm, smaller samples were used for the purpose of this research. For a description of the corpus, see the Appendix.

6 Although it is beyond the scope of this paper to discuss the differences between the different demonstrative forms, in Table 1 we can also see which demonstrative determiners are most frequently replaced by a Def NP in the other language. For Dutch, the distal form is more frequently replaced by a Def NP than the proximal form (17,8\% vs. $12,6 \%$; statistically significant: p 0.043). This confirms the commonly accepted tendency that the distal forms grammaticalize more easily or more rapidly than the proximal forms (Diessel 1999; Kirsner 1993). 
For Spanish, the alternation with Dutch Def NP is always exceptional, for all three elements. However, interestingly, of the three demonstratives, the marked distal aquel is most frequently translated by (or is used to translate) a Dutch Def NP (the difference between aquel and the total of este and ese is even statistically significant: $p$ 0.019). For the discussion in this paper it is, above all, important to see that both Dutch demonstrative forms show a clearer tendency to correspond to a Def NP than their Spanish counterparts.

7 As was pointed out, especially in the French tradition (Gary-Prieur and Noailly 1996; de Mulder 1998, 2001; Kleiber 2006), in literary texts the recognitional use of the demonstratives can be exploited by the narrator to invite the reader to participate in his universe, adding the new elements that are required to establish a shared memory. This can create particular dynamic effects in the literary text.

${ }^{8}$ I have steered clear from creating radical, binary contrasts between examples where the translation shift would be due to a translator's decision or a cross-linguistic difference. Rather, I have tried to define several phenomena wich seemed to be primarily motivated by one of the two factors, and then examined the frequency of these phenomena in the corpus. Although this gives us indirect quantitative evidence for the explanatory qualitative discussion, this does not mean that the particular phenomenon is necessarily the only factor at work in a specific context. On the one hand, there are very few contexts where the translator is really obliged by the grammatical system to make one particular choice, and has no freedom to word things differently and on the other hand, in contexts where a free and creative choice was made, this was perhaps motivated by the judgment that a more literal translation would have been unidiomatic.

${ }^{9}$ Since the corpus consists of samples of the translated texts, not all these cases are included in the quantitative analysis: 6 out of the 15 cases occur in the fragments on which the data in Table 1 are based.

\section{References}

ANS. 1997. Algemene Nederlandse Spraakkunst. http://www.let.ru.nl/ans/e-ans/ (accessed 9 january 2012)

Botley, Simon Philip. 2006. Indirect anaphora. Testing the limits of corpus-based linguistics. International Journal of Corpus Linguistics 11, 73-112.

Brisard, Frank (ed.) 2002. Grounding: The epistemic footing of deixis and reference. Berlin: Mouton de Gruyter.

Bühler, Karl. 1934. Sprachtheorie. Die Darstellungsfunktion der Sprache. Jena: Fischer.

Consten, Manfred, Mareile Knees \& Monika Scharz-Friesel. 2007. The function of complex anaphors in texts: Evidence from corpus studies and ontological considerations. In Monika Schwarz-Friesel, Manfred Consten \& Mareile Knees (eds.), Anaphors in text. Cognitive, formal and applied approaches to anaphoric reference, 81-102. Amsterdam/Philadelphia: John Benjamins.

Cornish, Francis. 2007. English demonstratives: Discourse deixis and anaphora. A discoursepragmatic account. In Randi A. Nilsen, Nana Aba Appiah Amfo \& Kaja Borthen (eds.), Interpreting Utterances: Pragmatics and Its Interfaces, 147-166. Oslo: Novus Press.

Cuenca, María Josep \& Josep Ribera i Condomina. 2011. Deictic neutralisation and overmarking in translating fiction (English-Catalan). Paper presented at Paper presented at CILC 2011, Valencia.

Cysouw, Michael \& Bernhard Wälchli. 2007. Parallel texts: Using translational equivalents in linguistic typology. Sprachtypologie und Universalienforschung. Special Issue 60, 9599.

Da Milano, Federica. 2007. Demonstratives in parallel texts: a case study. Parallel Texts: Using translational equivalents in linguistic typology. Special Issue of Sprachtypologie und Universalienforschung 60, 135-147.

De Mulder, Walter. 1998. Du sens des démonstratifs à la construction d'univers. Langue française 120, 21-32.

De Mulder, Walter. 2001. Peut-on définir les SN démonstratifs par leurs contextes ? In Hennig Kronning \& et alii (eds.), Langage et référence, 115-123. Uppsala: Acta 
Universitatis Upsaliensis.

Delbecque, Nicole. 2011. Los usos no situacionales de los demostrativos españoles: enfoque cognitivo. In Elia Hernández Socas, Carsten Sinner \& Gerd Wotjak (eds.), Estudios de tiempo y espacio en la gramática española, 155-174. Frankfurt am Main: Peter Lang.

Diessel, Holger. 1999. Demonstratives: Form, function, and grammaticalization (Typological Studies in Language (TSLang): 42). Amsterdam: Benjamins.

Diessel, Holger. 2006. Demonstratives, joint attention, and the emergence of grammar. Cognitive Linguistics 17, 463-489.

Dixon, R. M. W. 2003. Demonstratives: A cross-linguistic typology. Studies in Language: 27, 61-112.

Eguren, Luis. 1999. Pronombres y adverbios demostrativos. Las relaciones deícticas. In Ignacio Bosque \& Violeta Demonte (eds.), Gramática Descriptiva de la Lengua Española, 929-972. Madrid: Espasa.

Epstein, Richard. 2002. Grounding, subjectivity and definite descriptions. In Frank Brisard (ed.), Grounding: The epistemic footing of deixis and reference, 41-81. The Hague: Mouton de Gruyter.

García Fajardo, Josefina. 2006. La instrucción de contrastar en el demostrativo español. Verba 33, 175-186.

Gary-Prieur, Marie-Noëlle \& Michèle Noailly. 1996. Démonstratifs insolites. Poétique 105, 111-121.

Genette, Gérard. 2007. Discours du récit. Essai de méthode. Paris: Seuil.

Goethals, Patrick. 2007. Corpus-driven hypothesis generation in translation studies, contrastive linguistics and text linguistics. A case study of demonstratives in Spanish and Dutch parallel texts. Belgian Journal of Linguistics 21, 87-104.

Goethals, Patrick \& July De Wilde. 2009. Deictic center shifts in literary translation: the Spanish translation of Nooteboom's Het Volgende Verhaal. Meta 54, 770-794.

Gómez Díez, Isabel. 2009. Los demonstrativos en español: ¿un sistema ternario? Análisis cuantitativo de un corpus de teatro español contemporáneo. In Rita de Maeseneer \& et al. (eds.), El hispanismo omnipresente: homenaje a Robert Verdonk 183-197. Brussel: University Press Antwerp.

Himmelmann, N. 1996. Demonstratives in narrative discourse: A taxonomy of universal uses. In B. Fox (ed.), Studies in Anaphora, 205-254. Amsterdam: Benjamins.

Johansson, Stig. 2007. Seeing through multilingual corpora. On the use of corpora in contrastive studies (Studies in Corpus Linguistics). Amsterdam: John Benjamins.

Jonasson, Kirsten. 2001. Traduction et point de vue narratif. In O. Eriksson (ed.), Aspekter av litterär översättning från franska. Kollokvium vid Växjö universitet 11-12 maj 2000, 69-81. Växjö: Växjö University Press.

Jonasson, Kirsten. 2002. Références déictiques dans un texte narratif. Comparaison entre le français et le suédois. In M. Kesik (ed.), Référence discursive dans les langues romanes et slaves, Actes du Colloque International de Linguistique textuelle, Lublin 24-30 septembre 2000, 107-121. Lublin: Wydawnictwo UMCS.

Jungbluth, Konstanze. 2001. Binary and ternary deictic systems in speech and writing. Evidence from the use of demonstratives in Spanish. Philologie in Netz 15, 1-24.

Jungbluth, Konstanze. 2003. Deictics in the conversational dyad. Findings in Spanish and some cross-linguistic outlines. In Friedrich Lenz (ed.), Deictic conceptualisation of space, time, and person, 13-40. Amsterdam: John Benjamins.

Kirsner, Robert S. 1979. Deixis in discourse: an exploratory quantitative study of the modern Dutch demonstrative adjectives. In Talmy Givón (ed.), Syntax and Semantics, Volume 12: Discourse and Syntax, 355-375. New York: Academic Press.

Kirsner, Robert S. 1993. From meaning to message in two theories: Cognitive and Saussurean 
views of the Modern Dutch demonstratives. In Richard Geiger \& Brygida RudzkaOstyn (eds.), Conceptualizations and Mental Processing in Language, 81-114. Berlin: Mouton de Gruyter.

Kleiber, Georges. 1986. Déictiques, embrayeurs, 'token-reflexives', symboles indexicaux, etc... : comment les définir ? L'Information grammaticale 30, 3-22.

Kleiber, Georges. 2003. Adjectifs démonstratifs et point de vue. Cahiers de praxématique 41, $33-54$.

Kleiber, Georges. 2006. Démonstratifs: emplois à la mode et mode(s) d'emploi. Langue Française 152, 9-23.

Labrador, Belén. 2011. A corpus-based study of the use of Spanish demonstratives as translation equivalents of English demonstratives. Perspectives 19, 71-87.

Langacker, Ronald. 2002. Deixis and subjectivity. In Frank Brisard (ed.), Grounding: The epistemic footing of deixis and reference, 1-28. Berlin: Mouton de Gruyter.

Levinson, Stephen. 2004. Deixis. In Laurence Horn \& Gregory Ward (eds.), The Handbook of Pragmatics, 97-121. Blackwell.

Lyons, Christopher. 1999. Definiteness. Cambridge: Cambridge University Press.

Lyons, John. 1977. Semantics. Cambridge: Cambridge University Press.

Macías Villalobos, Cristóbal. 2006. El demostrativo en Miguel Delibes. San Vicente de Raspeig: Taller Digital de Establecimiento de Textos Literarios y Científicos.

Maes, Alfons. 1996. Nominal anaphors, markedness and coherence of discourse. Leuven: Peeters.

Maes, Alfons. 2007. Spatial and conceptual demonstratives. In Iørn Korzen \& Lita Lundquist (eds.), Comparing Anaphors - Between Sentences, Texts and Languages, 127-144. Copenhagen: Samfundslitteratur Press.

Maes, Alfons \& Leo Noordman. 1995. Demonstrative nominal anaphoras: a case of nonidentificational markedness. Linguistics 33, 255-282.

Mason, Ian \& Adriana Şerban. 2003. Deixis as an interactive feature in literary translations from Romanian into English. Target 15, 269-294.

NGRAE. 2009. Nueva gramática de la lengua española. Real Academia Española. Madrid: Espasa.

Philippe, Gilles. 1998. Les démonstratifs et le statut énonciatif des textes de fiction : l'exemple des ouvertures de roman. Langue française 120, 51-65.

Piwek, Paul, Robbert-Jan Beun \& Anita Cremers. 2007. 'Proximal' and 'distal' in language and cognition: Evidence from deictic demonstratives in Dutch. Journal of Pragmatics 40, 694-718.

Vanderbauwhede, Gudrun, Piet Desmet \& Peter Lauwers. 2011. The shifting of the demonstrative determiner in French and Dutch in parallel corpora: from translation mechanisms to structural differences. Meta: Journal des Traducteurs 56, 443-464.

Wälchli, Bernhard. 2007. Advantages and disadvantages of using parallel texts in typological investigations. Sprachtypologie und Universalienforschung 60, 118-134.

Whittaker, Sunniva. 2004. Étude contrastive des syntagmes nominaux démonstratifs dans des textes traduits du français en norvégien et des textes sources norvégiens : stratégie de traduction ou translationese ? Forum 2, 221-240.

Wu, Yi'an. 2004. Spatial demonstratives in English and Chinese. Amsterdam: John Benjamins. 